\title{
Isolasi Candida albicans dari Swab Mukosa Mulut Penderita Diabetes Melitus Tipe 2
}

\section{Isolation of Candida albicans from Swab Mucosa Mouth Patient Diabetes Mellitus Type 2}

\author{
Ni Kadek Sri Jayanti ${ }^{1 a}$, I Nyoman Jirna ${ }^{2 b^{*}}$ \\ 1,2 Jurusan Analis Kesehatan, Poltekkes Kemenkes Denpasar, Indonesia \\ a Email address: ni.kadek.sri.jayanti@gmail.com \\ b Email address: nyomanjirna@ymail.com
}

\section{HIGHLIGHTS}

- Candida albicans were found in patient diabetes mellitus type 2

\section{ARTICLE INFO}

\section{Article history}

Received date : November $21^{\text {st, }} 2017$

Revised date : January $09^{\text {th }}, 2018$

Accepted date : February $27^{\text {th }}, 2018$

Keywords:

Candida albicans

Diabetes mellitus type 2

Oral mucosal swab

\section{Kata Kunci:}

Candida albicans

Diabetes mellitus tipe 2

Usapan mukosa mulut

\begin{abstract}
A B S T R A C T / A B S T R AK
Candida albicans can be pathogen when immunity had decreased and physiological function is impaired, such as in diabetes mellitus type 2. This study aims to isolation Candida albicans that collected from oral cavity of diabetes mellitus type 2 patients. This research is conducted with descriptive study by observing the presence of Candida albicans in 30 samples of diabetes mellitus type 2 patients, which grows on Potato Dextrose Agar. The microscopic observation by LPCB staining of yeasts, blastospores, pseudohyphae, chlamydospores and germ tubes in human serum suspension that incubated at $37^{\circ} \mathrm{C}$ for 2-3 hours. Based on this research was found 14 (46,7\%) patients from 30 patients were positive Candida albicans.
\end{abstract}

Candida albicans menjadi patogen saat kekebalan tubuh menurun dan fungsi fisiologis terganggu, seperti pada penderita diabetes mellitus. Penelitian ini bertujuan untuk mengisolasi Candida albicans yang dikumpulkan dari rongga mulut penderita diabetes melitus tipe 2 . Penelitian ini dilakukan dengan metode deskriptif dengan mengamati keberadaan Candida albicans pada 30 sampel pasien diabetes melitus tipe 2 yang tumbuh pada Agar Dextrose Kentang. Pengamatan secara mikroskopis dengan pewarnaan LPCB ragi, blastospora, pseudohifa, klamidiospora dan tabung kuman dalam suspensi serum manusia yang diinkubasi pada suhu $37^{\circ} \mathrm{C}$ selama $2-3$ jam. Berdasarkan hasil penelitian, dari 30 pasien diabetes melitus tipe 2 yang diteliti didapatkan hasil positif Candida albicans sebanyak 14 orang (46,7\%).

Copyright (C) 2018 Jurnal Teknologi Laboratorium. All rights reserved

\section{Corresponding Author:}

I Nyoman Jirna

Poltekkes Denpasar Jurusan Analis kesehatan

JIn. Sanitasi No 1. Denpasar Selatan, Telp. 0361710527

Email: nyomanjirna@ymail.com 


\section{PENDAHULUAN}

Candida albicans merupakan flora normal di permukaan membran mukosa, saluran pencernaan, dan saluran genitalia wanita. Candida albicans akan menjadi patogen apabila ada beberapa faktor risiko penyebab infeksi, seperti penurunan sistem imunitas dan terjadi perubahan fisiologis tubuh, salah satunya terjadi pada penderita diabetes melitus. Diabetes melitus (DM) merupakan suatu penyakit yang disebabkan oleh berbagai faktor yang ditandai dengan kadar gula darah yang tinggi sebagai akibat dari kegagalan fungsi kelenjar pankreas dalam menghasilkan insulin maupun kegagalan hati dalam menanggapi keberadaan insulin. ${ }^{1}$ Diabetes telah menyebabkan kematian sebanyak 1,5 juta jiwa, sedangkan diabetes dengan komplikasi menyebabkan kematian hingga 2,2 juta penduduk dunia pada tahun 2012 dengan usia dibawah 70 tahun. ${ }^{2}$ Berdasarkan data Rumah Sakit Umum Pusat (RSUP) Sanglah, total kunjungan pasien diabetes melitus hingga tahun 2016 mencapai 2.205 kasus yang didominasi oleh penderita diabetes melitus tipe $2 .^{3}$

Hasil penelitian pada swab mukosa mulut didapatkan hubungan antara kadar glukosa darah dengan pertumbuhan Candida albicans pada penderita DM yang tidak terkontrol. ${ }^{4}$ Penelitian lain menemukan peningkatan koloni Candida sp. pada pasien diabetes dibandingkan dengan orang normal. ${ }^{5}$ Penelitian terbaru, terdapat hubungan antara peningkatan kadar glukosa terhadap terjadinya kandidiasis oral pada penderita DM. ${ }^{6}$ Infeksi jamur Candida paling umum disebabkan oleh Candida albicans. Hasil penelitian pada 50 sampel pasien immunocompromised, didapatkan data jamur Candida albicans $86 \%$, Candida krusei $2 \%$, Candida tropicalis $4 \%$ dan Candida parapsilosis $2 \% .^{7}$

Penelitian ini bertujuan untuk mengisolasi Candida albicans yang ada pada rongga mulut penderita DM tipe 2 di RSUP Sanglah Denpasar, yang dapat bermanfaat sebagai bahan informasi mengenai risiko infeksi jamur Candida albicans pada penderita diabetes melitus tipe 2 dan sebagai bahan informasi bagi instansi kesehatan terhadap jamur Candida albicans yang teridentifikasi pada swab mukosa mulut penderita diabetes melitus tipe 2 .

\section{BAHAN DAN METODE PENELITIAN}

Jenis penelitian adalah penelitian deskriptif dengan desain cross sectional. ${ }^{8}$ Sampel penelitian berasal dari Poliklinik Diabetic Centre RSUP Sanglah, Denpasar. Kriteria inklusi adalah didiagnosis menderita diabetes melitus tipe 2, menjalani rawat jalan, berumur 15 tahun ke atas dan bersedia menjadi sampel. Jumlah sampel diambil sebanyak 30 sampel dengan ketentuan rumus estimasi sampel dan diperiksa di Laboratorium Bakteriologi Jurusan Analis Kesehatan Poltekkes Kemenkes Denpasar. Pengumpulan data dengan metode pemeriksaan dan pengamatan, prosedur kerja meliputi pembuatan media transport stuart dan media PDA (Pottato Dextro Agar), pengambilan dan kultur swab mukosa mulut dan pemeriksaan sampel. Pemeriksaan sampel jamur candida dilakukan secara mikroskopis, koloni Candida dengan pewarnaan larutan Lactophenol Cotton Blue (LPCB) dan pemeriksaan germ tubes metode inkubasi serum manusia

Data penelitian ini kemudian dikelompokkan dalam bentuk tabel dan narasi. Analisis data dilakukan secara deskriptif untuk mengetahui karakteristik Candida albicans yang ada pada rongga mulut penderita DM tipe 2 di RSUP Sanglah, Denpasar.

\section{HASIL DAN PEMBAHASAN}

Karakteristik jamur Candida albicans yang tumbuh pada media PDA suhu $37^{\circ} \mathrm{C}$ selama 36 jam yaitu koloni berbentuk bulat, ukuran koloni lebih besar dari koloni pada suhu ruang, konsistensi lembut, berwarna putih kekuningan atau cream, permukaan koloni halus dan berbau ragi yang khas (gambar 1 ). 


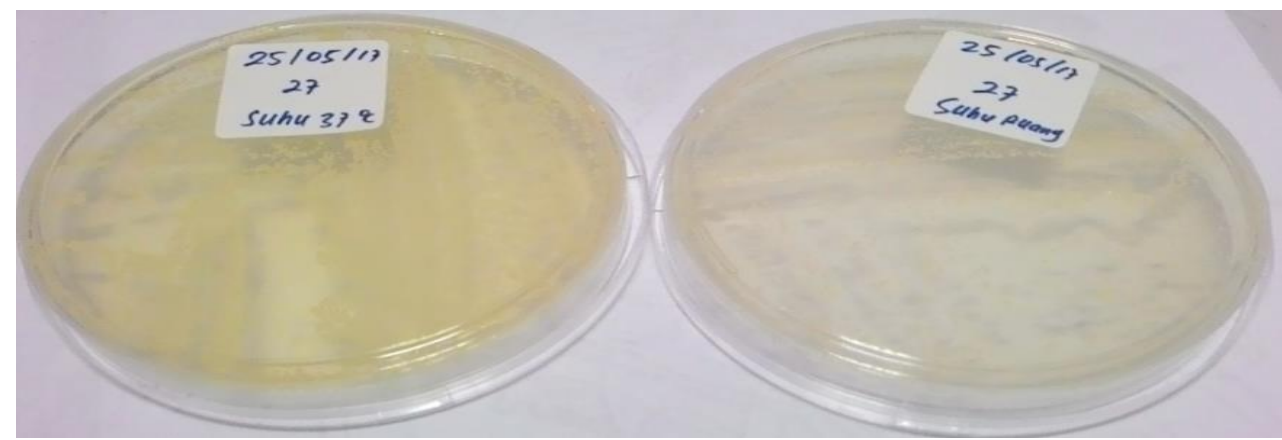

Gambar 1. Koloni Candida pada media PDA suhu $37^{\circ} \mathrm{C}$ (kiri) dan suhu ruang (kanan) Sumber: Data Primer (2017)

Hasil mikroskopis pada pewarnaan LPCB ditemukan adanya ragi, blastospora, pseudohifa, klamidospora dan beberapa terbentuk tabung tunas atau germ tubes yang berukuran lebih kecil, koloni tampak jelas berwarna biru (gambar 2).

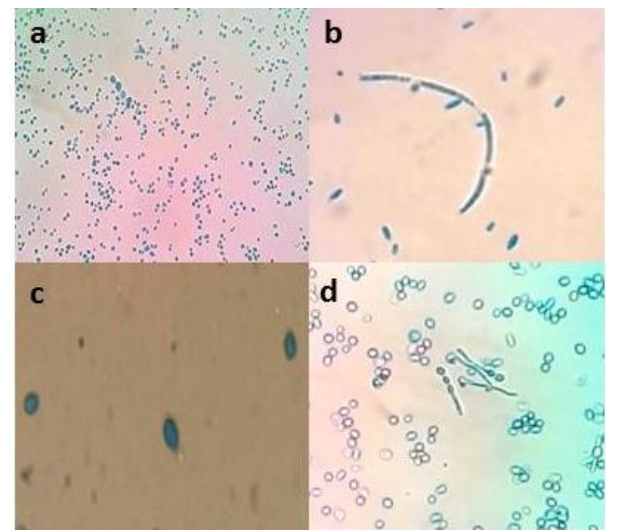

Gambar 2. Ragi dan blastospora (a), pseudohifa (b), klamidospora (c), dan germ tubes (d) Sumber: Data Primer (2017)

Pembentukan tabung tunas atau germ tubes pada serum manusia pada suhu $37{ }^{\circ} \mathrm{C}$ selama $2-3$ jam, lebih terlihat jelas dengan ukuran yang lebih besar dan jumlah yang terbentuk lebih banyak dibandingkan pada pewarnaan LPCB. Hasil mikroskopis ditemukan pseudohifa yang tampak sangat jelas ada percabangan (gambar 3 ).

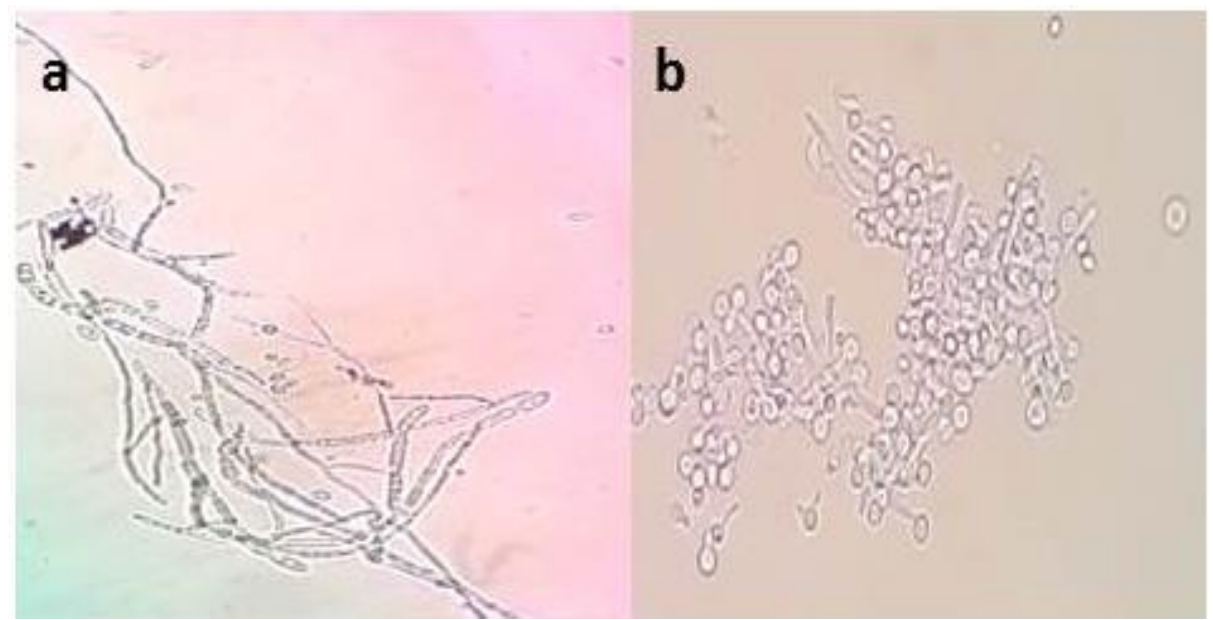

Gambar 3. Pseudohifa (a) dan germ tubes atau tabung tunas (b) Sumber: Data Primer (2017) 
Berikut akan disajikan hasil pemeriksaan pada 30 sampel penderita diabetes mellitus tipe 2 .

Tabel 1. Hasil Isolasi Candida albicans Berdasarkan Distribusi Frekuensi Penderita Candidiasis menurut Kelompok Umur di RSUP Sanglah, Denpasar

\begin{tabular}{|c|c|c|c|c|c|c|}
\hline \multirow[b]{2}{*}{ Usia (tahun) } & \multicolumn{4}{|c|}{ Candida albicans } & \multirow[b]{2}{*}{$\begin{array}{l}\text { Total } \\
\text { (Jiwa) }\end{array}$} & \multirow[b]{2}{*}{$\begin{array}{c}\text { Persentase } \\
\quad(\%)\end{array}$} \\
\hline & $\begin{array}{l}\text { Positif } \\
\text { (Jiwa) }\end{array}$ & $\begin{array}{c}\text { Persentase } \\
(\%)\end{array}$ & $\begin{array}{c}\text { Negatif } \\
\text { (Jiwa) }\end{array}$ & $\begin{array}{c}\text { Persentase } \\
(\%)\end{array}$ & & \\
\hline $31-40$ & 0 & 0 & 1 & 6 & 1 & 3 \\
\hline $41-50$ & 1 & 8 & 4 & 26 & 5 & 17 \\
\hline $51-60$ & 3 & 21 & 5 & 31 & 8 & 27 \\
\hline $61-70$ & 10 & 71 & 5 & 31 & 15 & 50 \\
\hline $71-80$ & 0 & 0 & 1 & 6 & 1 & 3 \\
\hline Total & 14 & 100 & 16 & 100 & 30 & 100 \\
\hline
\end{tabular}

Sumber: Data Primer (2017).

Tabel 2. Hasil Isolasi Candida albicans Berdasarkan Distribusi Frekuensi Penderita Candidiasis menurut Jenis Kelamin di RSUP Sanglah, Denpasar

\begin{tabular}{ccccccc}
\hline \multirow{3}{*}{ Jenis Kelamin } & \multicolumn{9}{c}{ Candida albicans } & $\begin{array}{c}\text { Total } \\
(\text { Jiwa })\end{array}$ & $\begin{array}{c}\text { Persentase } \\
(\%)\end{array}$ \\
\cline { 2 - 6 } & $\begin{array}{c}\text { Positif } \\
(\text { Jiwa) }\end{array}$ & $\begin{array}{c}\text { Persentase } \\
(\%)\end{array}$ & $\begin{array}{c}\text { Negatif } \\
(\text { Jiwa })\end{array}$ & $\begin{array}{c}\text { Persentase } \\
(\%)\end{array}$ & & \\
\hline Laki-laki & 7 & 50 & 10 & 62 & 17 & 57 \\
Perempuan & 7 & 50 & 6 & 38 & 13 & 43 \\
\hline Total & 14 & 100 & 16 & 100 & 30 & 100 \\
\hline
\end{tabular}

Sumber: Data Primer (2017).

Tabel 3. Hasil Isolasi Candida albicans Berdasarkan Lama Menderita DM di RSUP Sanglah, Denpasar

\begin{tabular}{ccccccc}
\hline $\begin{array}{c}\text { Lama Menderita } \\
\text { DM (tahun) }\end{array}$ & $\begin{array}{c}\text { Positif } \\
\text { (Jiwa) }\end{array}$ & $\begin{array}{c}\text { Persentase } \\
(\%)\end{array}$ & $\begin{array}{c}\text { Cegatif } \\
\text { (Jiwa) }\end{array}$ & $\begin{array}{c}\text { Persentase } \\
(\%)\end{array}$ & $\begin{array}{c}\text { Total } \\
\text { (Jiwa) }\end{array}$ & $\begin{array}{c}\text { Persentase } \\
(\%)\end{array}$ \\
\hline$<1$ & 2 & 14 & 0 & 0 & 2 & 7 \\
$1-10$ & 8 & 57 & 10 & 62 & 18 & 60 \\
$11-20$ & 3 & 21 & 4 & 25 & 7 & 23 \\
$>20$ & 1 & 8 & 2 & 13 & 3 & 10 \\
\hline Total & 14 & 100 & 16 & 100 & 30 & 100 \\
\hline
\end{tabular}

Sumber: Data primer (2017).

Hasil isolasi dan karakteristik jamur Candida albicans yang tumbuh pada media PDA yaitu koloni berbentuk bulat, konsistensi lembut, berwarna putih kekuningan atau cream dengan permukaan koloni halus serta berbau ragi yang khas. Hasil makroskopis ini sesuai dengan penelitian yang menemukan koloni muda berbentuk bulat, konsistensi lembut, berwarna cream dengan permukaan koloni yang halus. ${ }^{9}$

Hasil pewarnaan LPCB ditemukan adanya ragi, blastospora, pseudohifa, klamidospora, tampak berwarna biru jelas dan beberapa terbentuk tabung tunas atau germ tubes yang berukuran lebih kecil. Hal ini LPCB (Lactophenol Cotton Blue) yaitu cotton blue berfungsi memberi warna biru pada sel jamur, asam laktat yang berfungsi untuk memperjelas latar belakang dan mempertajam struktur jamur, gliserol berfungsi menjaga fisiologi sel dan menjaga sel terhadap kekeringan, serta kristal fenol untuk membunuh jamur.

Metode inkubasi koloni pada serum manusia, pembentukan tabung tunas atau germ tubes lebih terlihat jelas dengan ukuran yang lebih besar dan jumlah yang terbentuk lebih banyak dibanding pewarnaan LPCB. Penelitian yang membandingkan beberapa suspensi cairan untuk mempercepat pertumbuhan germ tubes baik dari hewan, buatan maupun serum manusia, 
didapatkan bahwa pembentukan germ tubes Candida albicans paling baik digunakan pada serum manusia yang telah diinkubasi selama 2 jam dengan hasil sensitivitas $98 \%$ dan spesifitas $100 \% .^{10}$ Penelitian pemeriksaan cepat Candida albicans dengan metode pembentukan germ tubes mendapatkan hasil sensitivitas $87,1 \%$ dan spesifitas $100 \%$. Candida albicans dapat ditentukan apabila ditemukan lebih dari 5 germ tubes pada satu koloni yang diamati. ${ }^{11}$

Hasil 14 sampel positif jamur Candida albicans, mengalami kondisi mulut kering yang ditandai dengan keinginan untuk banyak minum, hasil observasi kondisi rongga mulut dalam keadaan kering dan juga lembab serta beberapa ditemukan adanya bercak keputihan disekitar rongga mulut. Adanya bercak keputihan dan ditandai dengan rasa gatal pada rongga mulut merupakan gejala dari kandidiasis oral. ${ }^{12}$ Hasil penelitian ditemukan bahwa terjadi peningkatan kasus hiposalivasi yaitu berkurangnya laju aliran saliva di rongga mulut pada pasien DM tipe 2 , dibandingkan dengan kelompok kontrol bukan penderita DM. ${ }^{13}$ Pasien dengan hiposalivasi memiliki tingkat risiko yang lebih tinggi terjadinya infeksi bakteri dan jamur Candida dalam air liur dibandingkan dengan mereka yang tidak hiposalivasi. Hiposalivasi merupakan suatu keadaan yang ditandai dengan kondisi mulut kering. Saliva atau air liur mengandung musin yaitu glikoprotein yang difungsikan sebagai perlindungan terhadap kekeringan, sebagai pelumas, dan anti mikroba jaringan mulut. Musin juga berkontribusi sebagai kontrol kolonisasi bakteri dan jamur. Histatins dalam saliva merupakan protein kaya histidin yang menghambat pertumbuhan Candida albicans. ${ }^{14}$

Penderita tidak mengkonsumsi obat antifungi. Obat yang paling sering dikonsumsi yaitu antibiotik. Seperti yang diketahui, antibiotik dapat menekan pertumbuhan bakteri termasuk juga bakteri normal pada rongga mulut. Adapun bakteri normal yang menguntungkan bagi manusia yaitu Lactobacillus acidophilus. Bakteri ini berperan dalam menjaga pertumbuhan jamur Candida agar tetap seimbang. Bakteri Lactobacillus dapat mengurangi perlekatan jamur Candida albicans dengan cara: memproduksi bakteriosin dan juga melepaskan hidrogen peroksida dan asam laktat yang dapat menghambat proliferasi dan invasi jamur Candida albicans. ${ }^{15}$

Infeksi jamur Candida pada DM tipe 2 dikaitkan pada kadar gula darah serta gula kulit yang tinggi. Menurut Saskia dan Mutiara (2015), jamur merupakan mikroorganisme konsumen yang sangat bergantung pada medium yang menyediakan karbohidrat, protein, vitamin dan persenyawaan kimia lainnya, yang diperoleh dengan cara menyerap unsur yang dibutuhkan dari lingkungan hidupnya melalui sistem hifa. ${ }^{16}$ Kadar gula kulit merupakan 55\% kadar gula darah pada orang yang bukan diabetes, sedangkan pada penderita diabetes rasio meningkat hingga $69 \%$ $71 \%$ dari glukosa darah yang sudah meningkat. Pada penderita yang sudah berobat, rasionya melebihi $55 \% .^{17}$

Kondisi hiperglikemia juga menyebabkan terjadinya gangguan mekanisme sistem imunoregulasi. ${ }^{16} \mathrm{Hal}$ ini menyebabkan menurunnya daya kemotaksis, fagositosis dan kemampuan bakterisidal sel leukosit sehingga kulit lebih rentan terinfeksi. Hasil penelitian yang membandingkan aktifitas fagosit pada penderita DM tipe 2 dan bukan penderita DM menemukan bahwa terjadi penurunan persentase aktifitas fagosit pada penderita DM tipe $2 .{ }^{18}$ Aktifitas fagosit juga dihubungkan dengan penderita yang melakukan kontrol gula darah, terjadi peningkatan aktifitas fagosit pada penderita yang melakukan kontrol gula darah. Peningkatan aktifitas fagosit berperan dalam mencegah infeksi pada penderita diabetes melitus.

Terdapat hubungan antara kadar glukosa darah dengan pertumbuhan Candida albicans pada mukosa mulut penderita diabetes melitus yang tidak terkontrol. ${ }^{4}$ Candida albicans masih ditemukan pada penderita DM yang telah diobati, tetapi penderita tersebut masih memiliki kadar gula darah diatas normal. ${ }^{17}$

Penelitian ini mendukung hasil penelitian, yang menemukan ada peningkatan kolonisasi Candida pada mukosa mulut pasien diabetes dibandingkan dengan orang normal. ${ }^{5}$ Ada hubungan antara peningkatan kadar glukosa terhadap terjadinya Candidiasis oral pada penderita diabetes mellitus. ${ }^{6}$ Penyakit ini dapat menyebabkan infeksi secara lokal maupun sistemik yang sangat berbahaya. $^{12}$

Hasil positif Candida albicans pada 7 laki-laki dan 7 orang perempuan penderita DM tipe 2, jika dihubungkan dengan teori, perempuan lebih rentan terhadap penyakit autoimun karena siklus hormonal. Berdasarkan hasil penelitian Farizal (2017), didapatkan prevalensi positif jamur Candida albicans pada saliva wanita penderita DM di RSUD dr. M. Yunus Bengkulu, sebanyak $52 \% .{ }^{19}$ Hormon merupakan komponen sistem neuroendokrin yang dapat mempengaruhi imunitas 
seseorang. Apabila terjadi ketidakseimbangan sintesis dan pelepasan hormonal, maka hormon akan beraksi sebagai stimulator atau supresor aktifitas imun dan neuroendokrin itu sendiri dengan cara berikatan pada reseptor. Hormon estrogen dan prolaktin merupakan sitokin proinflamasi yang fluktuasinya dapat menggangu toleransi terhadap sel sendiri, sehingga dapat menjadi faktor pemicu penyakit autoimun. ${ }^{20}$ Berdasarkan tingkat usia ditemukan positif Candida albicans pada usia lanjut (61-70) tahun sebanyak 10 orang. Usia lanjut ditandai dengan proses penuaan. Penuaan adalah suatu proses menghilangnya secara perlahan kemampuan sel atau jaringan untuk memperbaiki diri atau mengganti diri dan mempertahankan struktur dan fungsi normalnya sehingga tidak dapat bertahan dari infeksi dan memperbaiki kerusakan yang diderita. Penurunan fungsi sel tersebut menyebabkan lebih mudah timbulnya masalah kesehatan pada usia lanjut. Berdasarkan lama menderita DM, Candida albicans ditemukan paling banyak pada rentang 1-10 tahun, yaitu sebanyak 8 orang. Komplikasi menyebabkan penurunan kualitas penderita DM. Hal lain juga disebabkan karena diabetes sering tidak terdeteksi atau mulai terjadinya diabetes adalah 7 tahun sebelum terdiagnosis, sehingga morbiditas dan mortalitas terjadi pada kasus yang tidak terdeteksi. ${ }^{21}$ Dalam penelitian ini juga ditemukan pertumbuhan jamur Candida albicans pada penderita DM tipe 2 yang telah menderita lebih dari 15 tahun. Rata-rata gejala komplikasi terjadi 15 - 20 tahun setelah terjadi peningkatan kadar gula darah. ${ }^{22}$

\section{SIMPULAN dan SARAN}

Karakteristik jamur Candida albicans pada media PDA yaitu koloni bulat, konsistensi lembut, berwarna putih kekuningan atau cream dengan permukaan yang halus serta berbau ragi yang khas, pengamatan mikroskopis dengan pewarnaan LPCB ditemukan adanya ragi, blastospora, pseudohifa, klamidospora, dan terbentuk tabung tunas atau germ tubes pada inkubasi serum manusia. Dari 30 penderita DM yang diteliti didapatkan hasil positif jamur Candida albicans pada swab mukosa mulut penderita DM tipe 2 yaitu sebanyak 14 orang penderita dengan persentase 46,7\%. Berdasarkan jenis kelamin ditemukan 7 laki-laki dan 7 perempuan positif Candida albicans, sedangkan untuk kelompok umur 61-70 tahun ditemukan positif Candida albicans sebanyak 10 orang penderita, dan berdasarkan lama menderita DM pada rentang 1-10 tahun ditemukan positif Candida albicans sebanyak 8 orang penderita DM tipe 2. Diharapkan penderita DM tipe 2 selalu menjaga kebersihan dan kesehatan rongga mulut, serta rutin melakukan kontrol gula darah setiap satu bulan sekali sesuai dengan petunjuk dokter yang menangani.

\section{UCAPAN TERIMA KASIH}

Direktur Politeknik Kesehatan Kementerian Kesehatan Denpasar yang telah memberikan kesempatan melakukan pemeriksaan di laboratorium mikologi Jurusan Analis Kesehatan Politeknik Kesehatan Kementerian Kesehatan Denpasar.

\section{DAFTAR PUSTAKA}

1. Hasdianah H. Mengenal Diabetes Mellitus Pada Orang Dewasa Dan Anak-Anak Dengan Solusi Herbal. Yogyakarta: Nuha Medika; 2012. http://apps.who.int/iris/bitstream/10665/204871/1/9789241565257_eng.pdf.

3. Data Pasien Penderita Diabetes Melitus Tahun 2014-2016. Denpasar; 2016.

4. Hernawati S. Hubungan Kadar Glukosa Darah Dengan Pertumbuhan Candida Albicans pada Penderita Diabetes Melitus. J Dent Indones. 2007;14. http://www.jdentistry.ui.ac.id/index.php/JDI/article/view/821.

5. Pallavan B, Ramesh V, Dhanasekaran BP, Oza N, Indu S, Govindarajan V. Comparison And Correlation Of Candidal Colonization In Diabetic Patients And Normal Individuals. J Diabetes Metab Disord. 2014. http://link.springer.com/article/10.1186/2251-6581-13-66.

6. Sumintarti, Rahman F. Korelasi Kadar Glukosa Saliva Dengan Kadar Glukosa Darah 
Terhadap Terjadinya Kandidiasis Oral Pada Penderita Diabetes Melitus (Correlation Of Salivary Glucose Level And Blood Glucose Level With Oral Candidiasis In Diabetes Melitus Patient). 2015;14. http://jdmfs.org/index.php/jdmfs/article/viewFile/422/423.

7. Magare JD, Awasthi RS. Evaluating the Prevalence of CandidaSpecies in the Oral Cavity of Immunocompromised Patients. Int J Sci Res. 2014. http://www.ijsr.net/archive/v3i3/MDIwMTMxMDUw.pdf.

8. Notoatmodjo S. Metodologi Penelitian Kesehatan. Jakarta: Rineka Cipta; 2012.

9. Haw BP, Asma I, Eugene O, Sasidharan S. . Phenotyping Identification of Candida albicans for the Production of In House Helicase for Nucleic Acid-Based Detections for Fast Diagnosis. Res J Pharm Biol Chem Sci. 2013;4(2):576. http://www.rjpbcs.com/pdf/2013_4(2)/[64].pdf.

10. Hilmioglu I, Badak. Comparison of 12 liquid media for germ tube production of Candida albicans and C. tropicalis. https://www.ncbi.nlm.nih.gov/pubmed/17576320. Published 2007.

11. Sheppard DC, Locas MC, Restieri C, Laverdiere M. Utility of the Germ Tube Test for Direct Identification of Candida albicans from Positive Blood Culture Bottles. J Clin Microbiol. 2008;46:3508-3509. https://www.ncbi.nlm.nih.gov/pmc/articles/PMC2566088/.

12. Jawetz E, Melnick JL, Adelberg EA. Mikrobiologi Kedokteran. 25th ed. Jakarta: EGC; 2012.

13. Khovidhunkit SO, Suwantuntula T, Thaweboon S, Mitrirattanakul S, Chomkhakhai U, Khovidhunkit W. Serostomia, hyposalivation, and oral microbiota in type 2 diabetic patients:a $\begin{array}{llllll}\text { preliminary study. } & J & \text { Med } & \end{array}$ https://www.ncbi.nlm.nih.gov/pubmed/19772183.

14. Hafid PS. Pengaruh Berkumur Larutan Ekstrak Bonggol Nanas (Ananas comosus (L .) Merr.) Terhadap Peningkatan $\mathrm{pH}$ Saliva Rongga Mulut. http://repository.unhas.ac.id/handle/123456789/21302. Published 2016.

15. Andriyani S. Kandidiasis Oral Pada Pasien Tuberkulosis Paru Akibat Pemakaian Obat Antibiotik Dan Steroid (Laporan Kasus).(2011). http://repository.usu.ac.id/bitstream/handle/123456789/23362/Chapter II. pdf? sequence $=3 \&$ isAllowed $=y$.

16. Saskia TI, Mutiara H. Infeksi Jamur pada Penderita Diabetes Mellitus. http://jukeunila.com/wp-content/uploads/2015/11/69-74-TRESA-IS.pdf. Published 2015.

17. Sularsito SA. IImu Penyakit Kulit Dan Kelamin: Hubungan Kelainan Kulit Dan Penyakit Sistemik. 7th ed. Jakarta: Fakultas Kedokteran Universitas Indonesia; 2015.

18. Lecube A, Pachon G, Petriz J, Hernandez C, Simo R. Phagocytic Activity is Impaired in Type 2 Diabetes Mellitus and Increases after Metabolic Improvement. 2011.

19. Farizal J, Dewa EARS. Identifikasi Candida Albican pada Saliva Wanita Penderita Diabetes Melitus. J Teknol Lab. 2017;6(2):67-74. doi:https://doi.org/10.29238/teknolabjournal.v6i2.44

20. Wahyuni IS, Dewi TS, Herawati E, Zakiawati D. Profil Lesi Oral Pada Penderita Penyakit Autoimun. Maj Kedokt Gigi Indones. 2016;2. https://jurnal.ugm.ac.id/mkgi.

21. Ramadhan N, Marissa N. Karakteristik Penderita Diabetes Mellitus Tipe 2 Berdasarkan Kadar Hba1c Di Puskesmas Jayabaru Kota Banda Aceh. 2015;2:49-56. http://download.portalgaruda.org/article. php?article $=434871 \& v a l=7741 \&$ title $=$ KARAKTERIS TIK PENDERITA DIABETES MELLITUS TIPE 2 BERDASARKAN KADAR HBA1C DI PUSKESMAS JAYABARU KOTA BANDA ACEH.

22. Isselbacher KJ, Braunwald C, Martin JB, Fauci AS, Kasper DL. Harrison: Prinsip-Prinsip IImu Penyakit Dalam. 13th ed. (Asdie AH, ed.). Jakarta: Buku Kedokteran EGC; 2000. 